NOTE

\title{
Temporal variation in sea trout Salmo trutta life history traits in the Erriff River, western Ireland
}

\author{
P. G. Gargan ${ }^{1, *}$, F. L. Kelly ${ }^{1}$, S. Shephard ${ }^{1}$, K. F. Whelan ${ }^{2}$ \\ ${ }^{1}$ Inland Fisheries Ireland, 3044 Lake Drive, Citywest Business Campus, Dublin, D24 Y265, Ireland \\ ${ }^{2}$ School of Biology \& Environment Science, University College Dublin, Dublin 4, Ireland
}

\begin{abstract}
The demographic and life history characteristics of sea trout Salmo trutta L. populations can be changed by a range of pressures in both freshwater and marine environments. Few long-term monitoring programmes are in place to assess temporal change in population dynamics. We analysed a 20 yr time series (1985-2004) using 15 sea trout population response variables in the Erriff River, western Ireland. Over this period, when time was considered as a categorical variable comprising 4 sequential periods of $5 \mathrm{yr}$, important life history changes were observed. The most dramatic of these changes corresponded with the period immediately after the commencement of salmon farming in the local estuary, with significant decreases in the number and length of sea trout kelts, the estimated number of eggs deposited, the sea trout rod catch, the proportion of older (1+ and $2+$ sea age) fish and the frequency of repeat spawners. We found a significant positive relationship between the number of salmon lice Lepeophtheirus salmonis in the local salmon farm and the number of lice found on sea trout collected contemporaneously in local rivers. Results of this long-term monitoring programme demonstrate that significant changes in sea trout population structure with respect to quantitative life history traits can occur over a relatively short time period and suggest that the introduction of salmon farming into the local estuary most likely contributed to the observed changes in sea trout population dynamics.
\end{abstract}

KEY WORDS: Sea trout $\cdot$ Salmo trutta $\cdot$ Fish population dynamics $\cdot$ Stock collapse $\cdot$ Salmon lice Lepeophtheirus salmonis $\cdot$ Ecological indicators

\section{INTRODUCTION}

Long-term data on sea trout population dynamics are rare. Previous studies have described the nature of sea trout populations and their life history characteristics (Nall 1930, Went 1962, Elliott 1985, Le Cren 1985, Jonsson, 1985, Solomon 1995, Davidson et al. 2006, Poole et al. 2006), but few long-term studies have described changes in population dynamics and examined possible underlying causes. A salmon and sea trout research programme began on the Erriff catchment in County Mayo on Ireland's west coast in 1983 to evaluate the health status of these populations, determine suitable management strategies to address identified impacts and apply findings to

*Corresponding author: paddy.gargan@fisheriesireland.ie

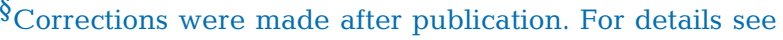
www.int-res.com/articles/aei2016/8/q008p691.pdf This corrected version: January 5, 2017 other salmonid catchments. Since 2014, the Erriff catchment has been designated by Inland Fisheries Ireland as the National Salmonid Index Catchment for Ireland. The Erriff fishery, entering Killary Harbour, has been an important salmon and sea trout angling fishery since the early $20^{\text {th }}$ century. A downstream Wolf-type trap (Wolf 1951) was constructed in 1984 in the Black River (Fig. 1), a tributary of the Erriff River located below Tawnyard Lough, to collect information on sea trout smolt and kelt (i.e. fish surviving after spawning) runs. This downstream trap is 1 of only 2 long-term sites monitoring salmonid runs in the Republic of Ireland; the other is on the Burrishoole River, which is also in County Mayo.

() The authors 2016. Open Access under Creative Commons by Attribution Licence. Use, distribution and reproduction are unrestricted. Authors and original publication must be credited. 
In 1986, marine salmon farming began in Killary Harbour into which the Erriff discharges. Marine salmon farming also commenced in most of the suitable bays in the mid-west region in the mid-1980s. Concurrently, by 1989, all of the major sea trout fisheries in the mid-west region had suffered dramatic collapses in rod catch (Poole et al. 1996, Gargan 2000). The long-term programme in the Erriff, which was started prior to the observed collapse in sea trout rod catch, provides an opportunity to examine and document sea trout population responses to environmental change over a $20 \mathrm{yr}$ period. We used a $20 \mathrm{yr}$ time series to assess changes in population characteristics and to investigate possible causes.

The various terms to describe the life history characteristics of sea trout follow the international Standard Nomenclature proposed by Allan \& Ritter (1977). The numerical formula used to describe pre-smolt and post-smolt life history stages of sea trout are based on the conventions adopted by Nall (1930), Went (1962) and Harris (2006). For example, a 2 yr old smolt, having returned to fresh water in the same year as its smolt migration, is denoted as 2.0+, the decimal point indicating the smolt migration to the sea. The term 'maiden' refers to any adult fish that will spawn for the first time (Harris 2006). The term 'sea age' (or post-smolt age) refers to the number of years post migration (e.g. 0 sea age refers to $<1$ full year post-migration, i.e. a finnock).

\section{MATERIALS AND METHODS}

\section{Study area}

Salmon angling is carried out along the lower $10 \mathrm{~km}$ length of the main channel of the Erriff River, while Tawnyard Lough, the largest accessible lake to migratory fish on the system, is the principal sea trout fishery. It joins the main stem of the Erriff River, via the Black River (Fig. 1). The Erriff has a catchment area of $166.3 \mathrm{~km}^{2}$, while the Tawnyard subcatchment has an area of $11.3 \mathrm{~km}^{2}$. Tawnyard Lough has a surface area of 56 ha and has 1 major spawning tribu-

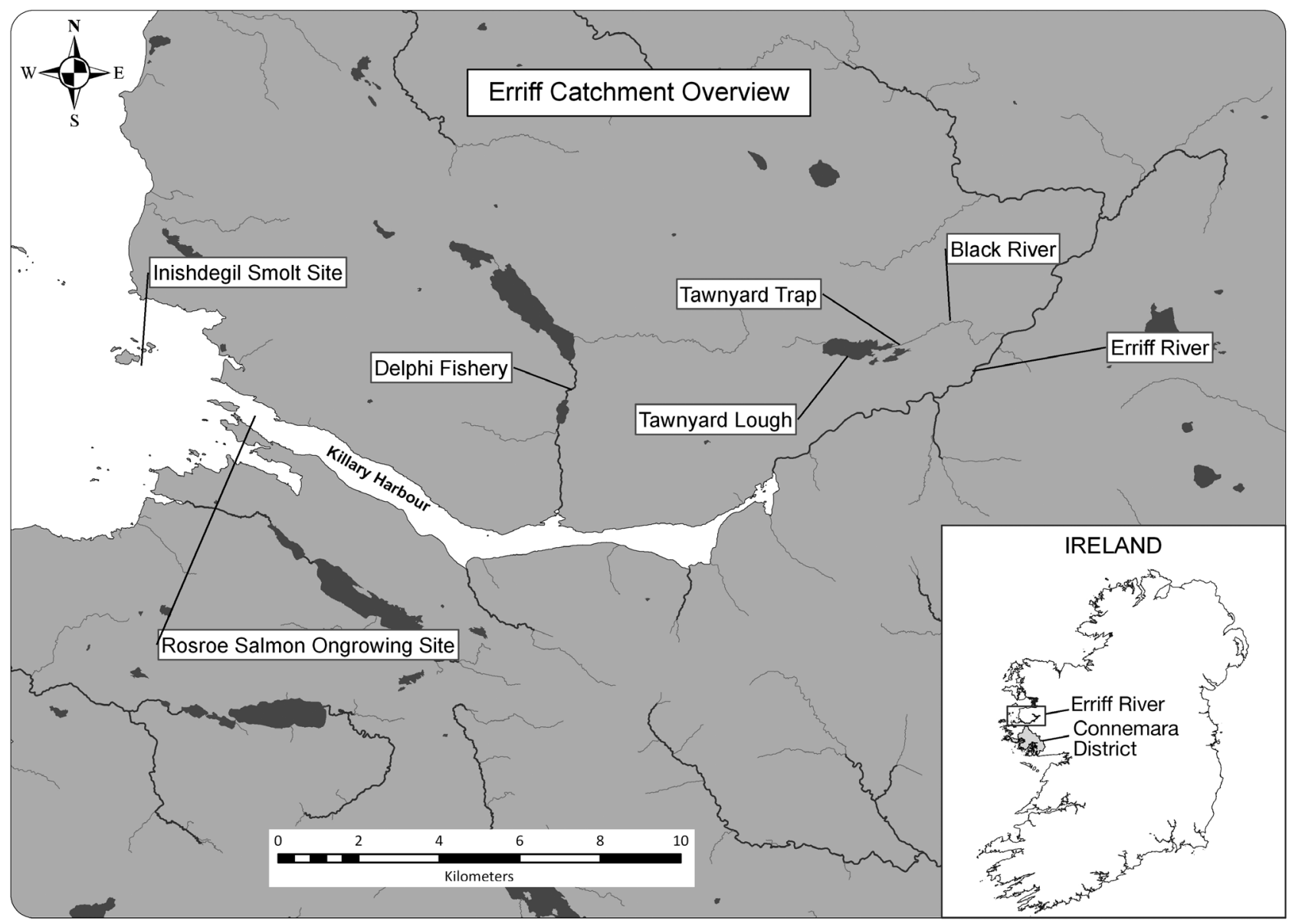

Fig. 1. Erriff Catchment and Killary Harbour Overview, western Ireland 
tary, the Glendavock (6 $\mathrm{km}$ in length), and 3 smaller spawning tributaries. The subcatchment is at a surface level of $70 \mathrm{~m}$, and the principal soil type comprises blanket peat with the underlying bedrock deriving from the Ordovician period. The subcatchment is very sparsely populated, and the main agricultural practice is sheep farming with some coniferous forestry. Over the duration of the study, little or no change occurred in farming practices within the Glendavock catchment. Fish species present in Tawnyard Lough include trout Salmo trutta L., salmon Salmo salar L., three-spined stickleback Gasterosteus aculeatus and eel Anguilla anguilla L. The Black River, the stream flowing out of Tawnyard, is a small spawning and nursery channel with no angling. The Erriff River downstream of the junction with the Black River is a major salmon spawning channel with little sea trout production and some sea trout angling potential. The Erriff River flows into the sea at the head of Killary Harbour. A salmon farm with licenced annual production ranging from 1200 to $2200 \mathrm{t}$ over the study period is located $14.8 \mathrm{~km}$ from the mouth of the river at the exit of the harbour. An estimate of the number of overwintered 1 sea winter salmon present over the period 1987-2004 is shown in Table 1. The Connemara fishery district borders the Erriff catchment to the southwest (Fig. 1), and annual sea trout rod catch data from 18 rod fisheries in the Connemara District and for the Erriff catchment are presented over the period 1975-2004 period (Fig. 2). The Burrishoole sea trout fishery enters Clew Bay, approximately $35 \mathrm{~km}$ north of Killary Harbour.

Only angling by rod was permitted on the Erriff River during the study period, and on Tawnyard Lough, fishermen were further restricted to fly fishing from a boat. Draft net fishing for salmon operated in Killary Harbour throughout the study period, as did drift net fishing for salmon outside Killary Harbour. Bottom trawling for prawn and shrimp takes place in Killary Harbour, and seasonal trawling for herring also occurs both inside and outside Killary Harbour. Mussel farming has been operating in Killary Harbour since the late 1970s.

\section{Trapping facility}

A downstream Wolf-type trap has been in operation on the Black River downstream of Tawnyard Lough since 1985. The trap consisted originally of a diagonal fish fence barrier with metal screens with $15 \mathrm{~mm}$ spacing across the entire river which diverts downstream migrants, both smolts and kelts, into a timber trap entrance (with sloped timber grids with $12 \mathrm{~mm}$ spacing) leading into a timber box trap. A new downstream trap was constructed $200 \mathrm{~m}$ farther downstream in 1987 with a fish fence screen of

Table 1. Estimates of the Atlantic salmon Salmo salar stock at Killary salmon farm, numbers of mobile salmon lice Lepeophtheirus salmonis on farmed fish (source: Marine Institute Annual Reports) and mean L. salmonis density (no. lice fish ${ }^{-1}$ ) on Erriff and Delphi sea trout Salmo trutta $(\mathrm{N} \geq 5)$. Blank: no data

\begin{tabular}{|c|c|c|c|c|c|c|}
\hline \multirow{2}{*}{ Year } & \multicolumn{2}{|c|}{ Killary } & \multicolumn{2}{|c|}{ Mobile farm } & \multirow{2}{*}{$\begin{array}{l}\text { Erriff sea trout } \\
\text { Mean L. salmonis }\end{array}$} & \multirow{2}{*}{$\begin{array}{l}\text { Delphi sea trout } \\
\text { Mean L. salmonis }\end{array}$} \\
\hline & $\begin{array}{c}\text { Smolt } \\
\text { no. }\left(\times 10^{4}\right)\end{array}$ & $\begin{array}{l}\text { Overwintered } \\
\text { no. }\left(\times 10^{4}\right)\end{array}$ & L. salmonis April & L. salmonis May & & \\
\hline 1986 & 8 & 0 & & & & \\
\hline 1987 & 12 & 7.5 & & & & \\
\hline 1988 & 20 & 12 & & & & \\
\hline 1989 & 30 & 18 & & & & \\
\hline 1990 & 30 & 29 & & & & 78.2 \\
\hline 1991 & 0 & 30 & 37 & 27 & 85.8 & \\
\hline 1992 & 8 & 0 & 0.51 & 0.4 & 0 & \\
\hline 1993 & 15 & 7.7 & 7.98 & 12.05 & 34.2 & 19.5 \\
\hline 1994 & 30 & 7.5 & 1.28 & 3.55 & 16.8 & 19 \\
\hline 1995 & 30 & 22 & 6.06 & 14.99 & 39 & 58.5 \\
\hline 1996 & 27.5 & 23 & 7.74 & 3.94 & 95.2 & 71.8 \\
\hline 1997 & 27.5 & 22 & 0.61 & 1.83 & 21.5 & \\
\hline 1998 & 38.9 & 24.9 & 0.03 & 0.55 & 10.5 & \\
\hline 1999 & 40 & 33.6 & 0.1 & 1.46 & 42.2 & 87.8 \\
\hline 2000 & 40 & 36 & 3.18 & 1.08 & 20.1 & 30.2 \\
\hline 2001 & 48 & 38.9 & 0.09 & 0 & 1.2 & \\
\hline 2002 & 48 & 43 & 0.43 & 0.19 & & \\
\hline 2003 & 65 & 44 & 1.22 & 1 & 41.4 & 40.2 \\
\hline 2004 & 65 & 34 & 1.33 & 0.57 & 11.2 & 42.5 \\
\hline
\end{tabular}


$12 \mathrm{~mm}$ spacing and was in operation there for the remainder of the study period. The larger spacing of the earlier fish fence screens may have allowed some smaller smolts pass through the screens. However, the diagonal orientation of the fish fence diverted the great majority of downstream migrants into the trap opening and no fish were recorded impinged on the screens over the study period. Metal screens adjacent to the trap are removed after June each year to allow ascending salmon and sea trout to enter Tawnyard Lough. No sampling of upstream migrants was undertaken. The traps were monitored daily and more frequently during runs of fish or periods of high water. Incidences of flood events and overtopping of the trap were also recorded (Table A1 in the Appendix). The earlier trap was more prone to overtopping during spates. The number of kelts recorded in 1986,
1992, 1993, 1998 and 1999 are minimum estimates, as overtopping of the trap occurred on at least 1 occasion in each of these years.

\section{Fish data}

The number and size of downstream migrating sea trout smolts and kelts was recorded at the trap over the period 1985-2004. Information on kelts was collected over the March to May period and reflected sea trout which migrated to sea in previous years and returned to Tawnyard Lough. Both spawned kelts and unspawned over-wintered finnock were recorded as sea trout kelts. Sea trout were categorised as kelts on the basis of being colour marked and finclipped or in the case of unmarked fish, on the basis

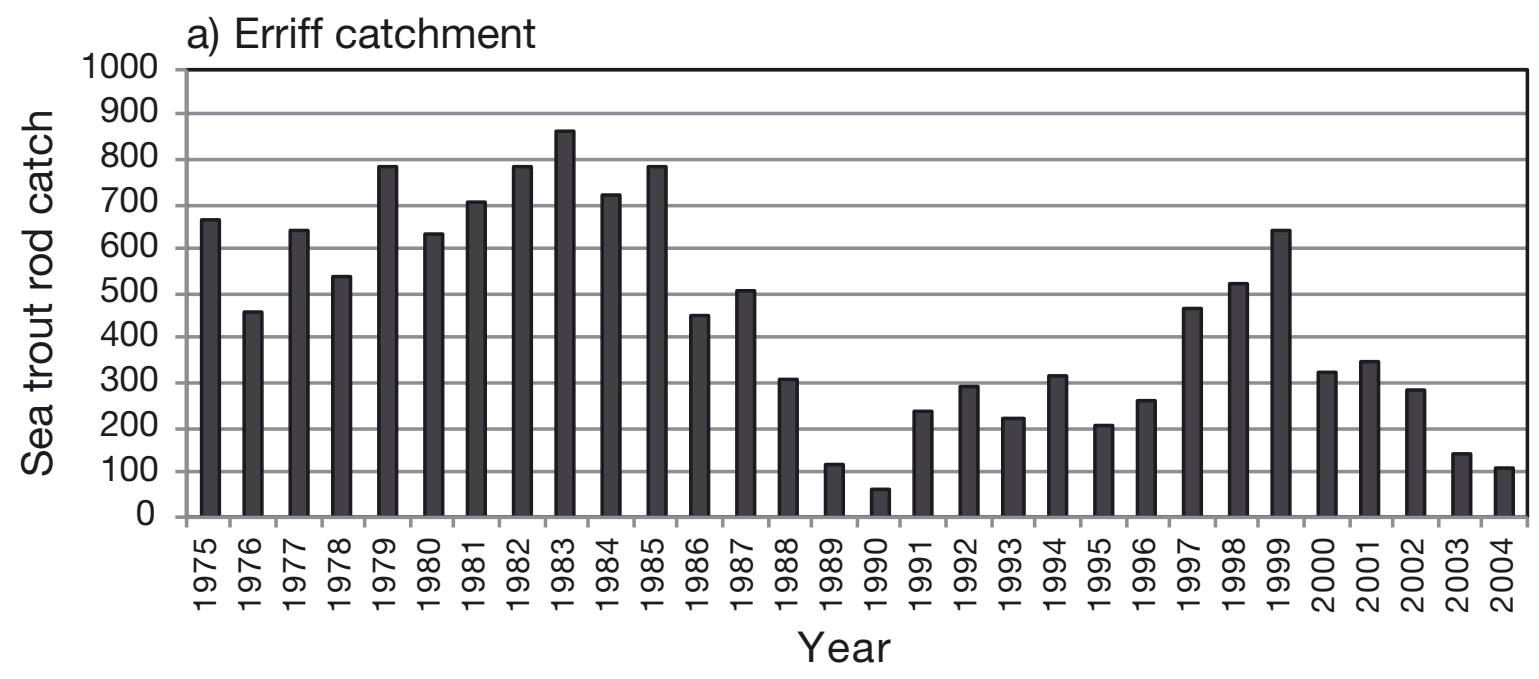

b) Connemara District

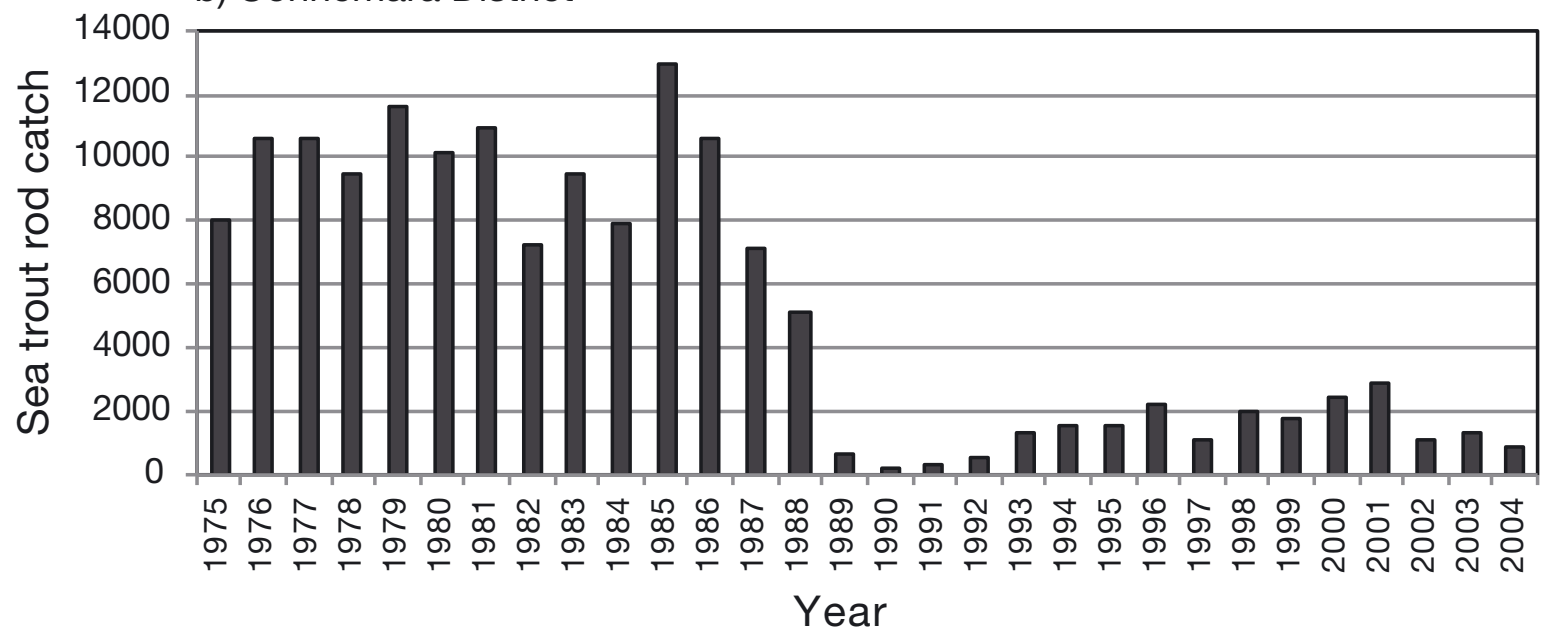

Fig. 2. Number of sea trout Salmo trutta rod catches for (a) the Erriff catchment and (b) the Connemara District, $1975-2004$. Catch and release angling was applied from 1990 onwards 
of length and condition. Over the period 1986-1999, sea trout smolts and kelts were marked with coloured dye at the base of the left pelvic fin and the adipose fin was clipped. Generally, a length of $>25 \mathrm{~cm}$ was used to distinguish smolts from kelts. A subsample of sea trout smolts and kelts were measured (total length, TL, cm) and a scale sample was taken. The duration and dates of each annual sampling period are shown in Table A1 in the Appendix. The trap was not in operation during 1989.

Over the time of the study, scales were examined from a total of 1122 sea trout smolts and 2710 kelts. Age was determined using scale analysis. Annuli in the river and sea zones of scales were identified and counted to indicate number of years spent in fresh water and in the sea, and spawning marks were recorded.

Sea trout rod catch for the Erriff catchment and for 18 fisheries in the neighbouring Connemara District to the southwest for the $30 \mathrm{yr}$ period 1975-2004 are shown in Fig. 2. After 1990, a bylaw was enforced, which permitted angling only on a catch-and-release basis in both the Erriff and Connemara fisheries. The introduction of the catch-and-release bylaw may have reduced fishing effort in Connemara and Erriff fisheries. However, based on analysis of sea trout rod catch per unit effort (CPUE) data for 4 Connemara fisheries, Gargan et al. (2006b) found that the sea trout catch decline recorded between 1988 and 1990 was not related to reduced angling effort and a marked reduction in CPUE had occurred.

The cumulative number of sea trout smolts recorded from 1985 to 2004 indicates that smolt runs begin in early April with the peak of the run occurring in late April to mid-May (Fig. 3). Start and finish dates indicate that trapping was in place during the peak smolt run in all years.

Records indicate that the main sea trout kelt run occurs between late March and mid-May with the peak of the run occurring during April. Trapping 'start and finish' dates (Fig. 3) indicate that the trap was monitored during the peak kelt run in all years apart from the first year of trapping in 1985, and data indicate that the kelt run occurs approximately $2 \mathrm{wk}$ earlier than the sea trout smolt run.

As part of the sea trout rehabilitation programme (Poole et al. 2002), initiated as a management response to the collapse in the sea trout fishery, a sea trout smolt and kelt reconditioning programme was initiated using Erriff sea trout. Erriff sea trout fry were stocked into Tawnyard streams in 1992 and continued until 2000, and stocking is assumed to have contributed to sea trout smolt production between 1994 and 2003. An estimate of the contribution of stocked trout fry was calculated based on an estimate of $2 \%$ of stocked fry surviving to the smolt stage

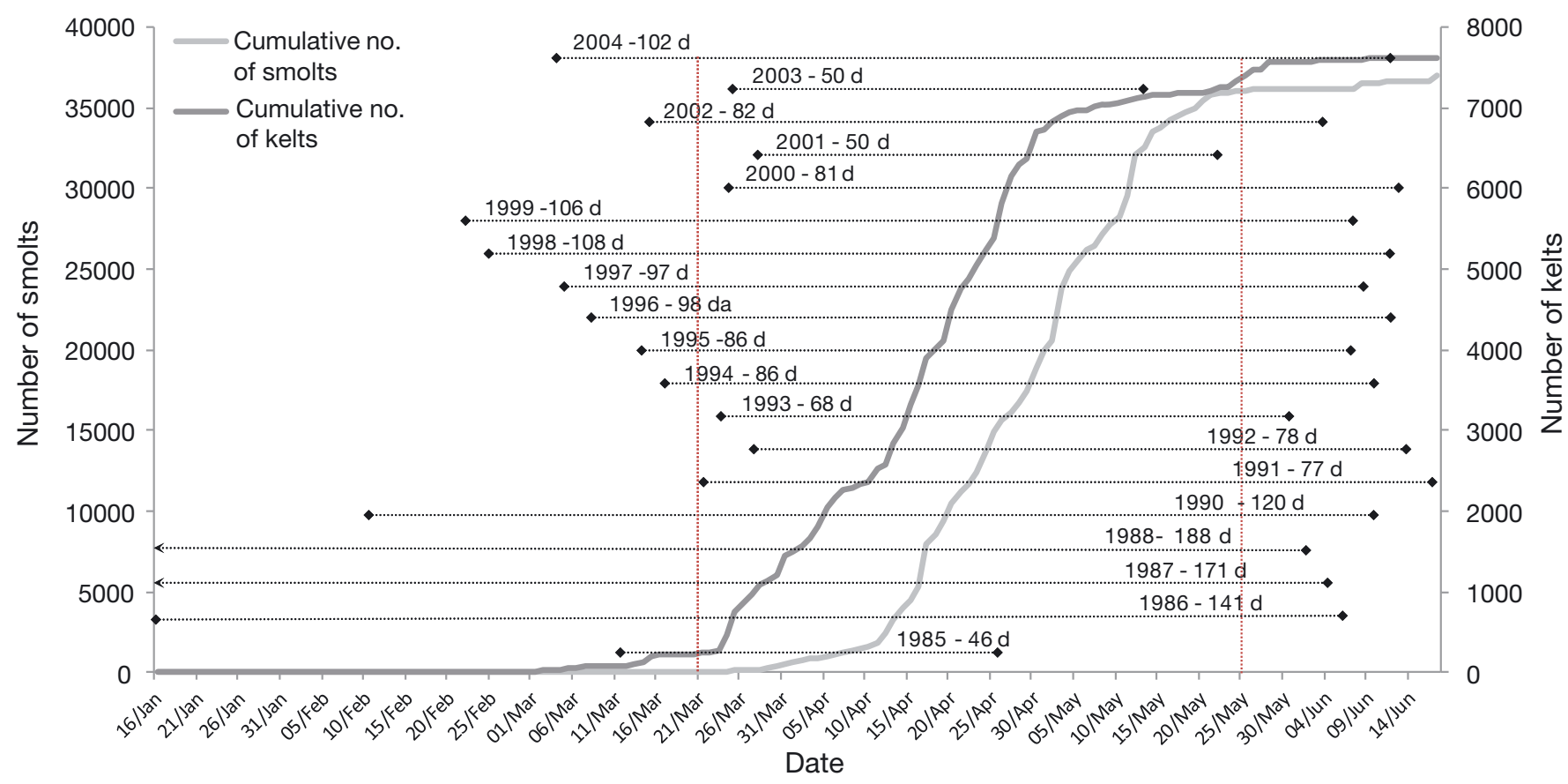

Fig. 3. Annual trapping duration on the Erriff River, and cumulative number of sea trout Salmo trutta smolts and kelts over a 20 yr period (1985-2004). Data were generated by adding the daily run of smolts and kelts by date each year. Red lines indicate main smolts and kelts run period 
(Fisheries Research Services 2002) The average age of Tawnyard smolts (37\% 2 yr, 58\% $3 \mathrm{yr}$ and 5\% 4 yr old smolts) was then used to estimate the number of smolts derived from stocking annually. This estimate was then taken from the total recorded Tawnyard smolt run to provide an estimate of the annual numbers of sea trout smolts, without the influence of stocking (see Table 3).

\section{Calculation of potential sea trout egg deposition}

Annual egg deposition was estimated using the following process:

(1) Fecundity (number of eggs deposited) at size (1 cm length classes) for kelts was calculated using the equation Fecundity $=60.67 \times$ Length - 1238.49, derived for Erriff sea trout in 1985 (O'Farrell et al. 1989).

(2) Fecundity-at-size estimates were raised to the annual number of sea trout kelts counted in each $1 \mathrm{~cm}$ length class, and then summed across age classes.

(3) Summed fecundity at size was multiplied by the estimated proportion of mature fish in the population (20.8\% at 0 sea age to $91.6 \%$ at 1 sea age and $100 \%$ at 2 sea age based on Tawnyard sea trout in 1983 and 1984) using a recorded kelt age-distribution.

(4) $36 \%$ was added to this value to account for sea trout overwinter mortality based on average overwintered kelt mortality derived from tagging studies in the Burrishoole system (Mills et al. 1990).

(5) The annual number of sea trout killed in Tawnyard Lough was added to provide a potential egg deposition rate.

(6) The resulting estimate of total egg deposition for the measured kelt sample was then raised to the total number of kelts in the annual run to give a total annual estimated potential egg deposition for the population.

\section{Sea lice monitoring}

Salmon farming began in Killary Harbour in 1986 with annual smolt numbers introduced into the net pens increasing significantly by the end of the 1980s (Table 1). Smolts were introduced to the Inishdegil site in spring of each year, and fish were moved to the Rosroe site in autumn for on-growing (Fig. 1). Fish were present at the Rosroe site in their second year of production over the entire study period, with the exception of 1992. Estimates of the number of overwintered salmon present at the end of April each year are based on best estimates from Fishery Inspector reports.

The Department of the Marine initiated a Sea Lice Monitoring programme for finfish farms in Ireland in 1991. Under this programme, adult female Lepeophtheirus salmonis and all mobile stages are counted and reported; larval stages were not recorded (Jackson \& Minchin 1993). Estimates of sea lice infestation pressure each spring were calculated by combining the average total number of mobile lice on individually sampled fish in April and May with the estimate of the total number of overwintered salmon present. Also, monitoring of sea lice levels on wild sea trout, generally covering the period 1 May to 15 June, has been ongoing in the Erriff and Delphi Rivers since 1990, and the data were reported previously by Tully et al. $(1993,1999)$ and Gargan et al. (2003).

\section{Data analysis}

The Erriff sea trout data comprised several different time series (typically covering the period 1985-2004) for a number of population descriptors (response variables) (Table 2). Statistical models (see below) were used to test for significant temporal changes in each of these response variables, where time was characterized using a categorical variable having 4 levels (Periods A, B, C and D). Each 'Period' was a consecutive 4 or $5 \mathrm{yr}$ sequence of the data (A: 1985-1988, B: 1990-1994, C: 1995-1999, D: 2000- 
2004). Exceptions were the 'number of lice on sea trout' (the data commenced in 1991 such that data for Period A were missing), and for 'rod catch' (the data covered the period 1974-2004 and all years up to 1989 were included in Period A. The Period variable was intended to capture shorter-term events, e.g. population decline and recovery, which might not be observable over larger time scales. 'Period' was structured such that the models compared each of Periods $\mathrm{B}, \mathrm{C}$ and $\mathrm{D}$ with the time period $\mathrm{A}$, where Period A refers to the time before marine salmon farming commenced close to the Erriff system.

Records of annual mean number of salmon lice per sea trout were available for the Erriff and the neighboring Delphi River. The models of number of salmon lice on sea trout included data from both rivers (Erriff and Delphi) and included 2 additional explanatory variables: river name and number of lice in the salmon farm in a given year. Estimates of sea lice infestation pressure from the farm were available for April and May annually; these estimates were considered as separate (collinear) covariates, and a separate model of number of lice per sea trout was implemented for each.

All count population response descriptors (numbers of smolts, kelts, eggs deposited, rod catch and salmon lice on sea trout) were modelled using negative binomial models. Length distributions for kelts and smolts were summarized as the annual $95^{\text {th }}$ percentile of length, and modelled using linear regression. Sea age of kelts (ages $0+$ and 1+) and age of migrating smolts (ages $2+, 3+$ and $4+$ ) were modelled as the proportion of fish in the population represented by each constituent age group; generalized linear models were applied with a binomial distribution (logit link). Data exploration plots were used to evaluate linearity, homogeneity and temporal autocorrelation in residuals of each model. All statistical analysis were conducted using the R statistical software (R Development Core Team 2010).

\section{RESULTS}

\section{Sea lice}

The mean abundance of salmon lice Lepeophtheirus salmonis recorded on sea trout captured from the Erriff and Delphi Rivers annually over the period 1990-2004, estimated numbers of salmon being farmed and recorded lice levels on the Rosroe salmon farm at the exit of Killary Harbour are shown in Table 1. There was a significant positive relationship between number of lice in the salmon farm in both April $(z=$ 2.97, p < 0.01) and May $(z=2.47, \mathrm{p}=0.01)$, and the number of lice on wild sea trout in the Delphi and Erriff Rivers in May and June. The number of lice on sea trout increased significantly $(z=2.42, p<0.05)$ between Periods B (1990-1994) and C (1995-1999).

\section{Rod catch}

There was a significant negative Period effect on Erriff sea trout rod catch, with catch being significantly greater over Period A (1975-1989) than in Periods B $(z=-4.21, \mathrm{p}<0.001)$ or D $(z=-3.93, \mathrm{p}<$ 0.001).

\section{Smolt data}

Analysis of the annual smolt run (Table 3) indicates that the number of smolts did not change significantly over the time series $(p>0.05)$. Sea trout smolt length varied from 14.5 to $29.9 \mathrm{~cm}$, while mean length varied from 19.75 to $22.65 \mathrm{~cm}$ between 1986 and 2002. There was a significant increase $(t=2.49, \mathrm{p}$ $=0.032$ ) in smolt length from Period A to Period B. The majority of sea trout smolt scales examined in this study were from 2 and $3 \mathrm{yr}$ old fish (Table 3), with an overall mean of 37 and $58 \%$ for 2 and $3 \mathrm{yr}$ old

Table 3. Annual sea trout Salmo trutta smolt run, percentage smolt age composition and mean length of smolts with standard deviation (SD). -: no data

\begin{tabular}{|c|c|c|c|c|c|c|c|}
\hline Year & $\begin{array}{l}\text { Smolt } \\
\text { run } \\
\text { total no }\end{array}$ & $\begin{array}{r}\% \mathrm{~s} \\
\text { per a } \\
2\end{array}$ & $\begin{array}{l}\text { Smo } \\
\text { ge c } \\
3\end{array}$ & $\begin{array}{l}\text { ts } \\
\text { lass } \\
4\end{array}$ & $\begin{array}{l}\text { Total } \\
\text { no. of } \\
\text { smolts }\end{array}$ & $\begin{array}{l}\text { Mean } \\
\text { length }\end{array}$ & $\begin{array}{l}\mathrm{SD} \\
(\mathrm{cm})\end{array}$ \\
\hline 1985 & - & 13 & 73 & 14 & 52 & - & - \\
\hline 1986 & 1017 & 44 & 51 & 5 & 251 & 19.75 & 2.11 \\
\hline 1987 & - & 24 & 71 & 5 & 42 & - & - \\
\hline 1988 & 2877 & 42 & 47 & 11 & 83 & 20.00 & 1.57 \\
\hline 1990 & 2426 & 34 & 56 & 9 & 64 & 20.06 & 1.57 \\
\hline 1991 & 3418 & 36 & 63 & 1 & 95 & 21.87 & 2.03 \\
\hline 1992 & 1818 & 16 & 65 & 19 & 43 & 22.16 & 1.74 \\
\hline 1993 & 420 & 58 & 40 & 2 & 52 & 22.65 & 2.05 \\
\hline 1994 & 1434 & 54 & 44 & 2 & 48 & 21.13 & 2.30 \\
\hline 1995 & 2808 & 39 & 61 & 0 & 28 & 21.25 & 1.75 \\
\hline 1996 & 3389 & 52 & 47 & 1 & 77 & 21.31 & 1.97 \\
\hline 1997 & 2825 & 42 & 56 & 2 & 90 & 20.02 & 2.40 \\
\hline 1998 & 3216 & 29 & 70 & 1 & 76 & 20.70 & 1.81 \\
\hline 1999 & 3355 & 37 & 61 & 2 & 60 & 20.90 & 1.81 \\
\hline 2000 & 1390 & - & - & - & - & 21.52 & 2.11 \\
\hline 2001 & 195 & - & - & - & - & - & - \\
\hline 2002 & 2768 & 39 & 59 & 2 & 61 & 19.82 & 1.88 \\
\hline 2003 & 2327 & - & - & - & - & - & - \\
\hline 2004 & 1865 & - & - & - & - & - & - \\
\hline
\end{tabular}


smolts, respectively. The proportion of $2+$ or $3+$ smolts has not changed significantly over time, i.e. there was no period effect $(p>0.05)$; however, the proportion of $4+$ smolts was significantly lower in Period $C$ than in Period A $(z=-3.34, p<0.001)$. Scale analysis revealed that the $3 \mathrm{yr}$ old age group were dominant in 12 of the $15 \mathrm{yr}$ examined.

\section{Sea age}

The proportion of $0+$ sea trout increased significantly over time (Table 4 ), with a greater proportion of $0+$ fish in Periods B $(z=6.13, \mathrm{p}<0.001), \mathrm{C}(z=$ 5.05, $\mathrm{p}<0.001)$ and $\mathrm{D}(z=2.83, \mathrm{p}=$ $0.005)$ compared to Period A. The proportions of $1+$ and $2+$ sea age fish and previous spawners decreased significantly over time; there were fewer $1+$ fish observed in the Tawnyard trap in Periods B $(z=-5.04, \mathrm{p}<$ $0.001)$ and $C(z=-2.83, p=0.004)$ compared to Period A, fewer $2+$ fish in Periods B $(z=-2.42, p=0.016)$ and C $(z=-3.63, p<0.001)$ compared to Period A, and fewer previous spawners in Periods B $(-=-2.96, \mathrm{p}=$ $0.003), C(z=-3.19, p=0.001)$ and $D(z=-2.15, p=$ 0.032 ) compared to Period A. The proportion of previous spawners varied considerably on the Black River between 1985 and 2004, ranging from 0\% in 1991-1993 and 2002 to $40 \%$ in 1988 (Table 4). Overall, the mean length of finnock (0+ fish) was $29.6 \mathrm{~cm}$ and the mean length for 1 sea winter fish was 38.4 cm.
Table 4. Percentage of sea trout Salmo trutta in each sea age class, percentage previous spawned sea trout and percentage sea trout kelts $>35 \mathrm{~cm}$. -: no data

\begin{tabular}{|ccccccccccc|}
\hline \multirow{8}{*}{ Year } & \multicolumn{1}{c}{ \% } & Trout per age class & \multicolumn{1}{c|}{ Total no. } & Previous spawners & \multirow{2}{*}{ \% Kelts } \\
& $0+$ & $1+$ & $2+$ & $3+$ & $4+$ & of trouts & Perc. & Total no. & $>35 \mathrm{~cm}$ \\
\hline 1985 & 56.0 & 30.1 & 12.2 & 0.0 & 0.7 & 409 & 18 & 169 & 44 \\
1986 & 79.4 & 18.0 & 2.6 & 0.0 & 0.0 & 422 & 17 & 506 & 35 \\
1987 & 65.5 & 32.6 & 1.9 & 0.0 & 0.0 & 423 & 12 & 482 & 43 \\
1988 & 42.6 & 39.7 & 16.1 & 1.7 & 0.0 & 242 & 40 & 406 & 49 \\
1990 & 64.2 & 26.4 & 9.4 & 0.0 & 0.0 & 53 & 2 & 44 & 21 \\
1991 & 94.3 & 5.7 & 0.0 & 0.0 & 0.0 & 35 & 0 & 35 & 4 \\
1992 & 100.0 & 0.0 & 0.0 & 0.0 & 0.0 & 20 & 0 & 13 & 5 \\
1993 & 100.0 & 0.0 & 0.0 & 0.0 & 0.0 & 24 & 0 & 4 & 0 \\
1994 & 90.0 & 10.0 & 0.0 & 0.0 & 0.0 & 70 & 24 & 92 & 22 \\
1995 & 84.8 & 12.1 & 3.0 & 0.0 & 0.0 & 33 & 10 & 21 & 21 \\
1996 & 69.6 & 30.4 & 0.0 & 0.0 & 0.0 & 23 & 18 & 28 & 21 \\
1997 & 82.1 & 16.7 & 1.2 & 0.0 & 0.0 & 84 & 7 & 90 & 15 \\
1998 & 66.0 & 33.0 & 0.9 & 0.0 & 0.0 & 106 & 17 & 115 & 21 \\
1999 & 88.1 & 11.9 & 0.0 & 0.0 & 0.0 & 84 & 18 & 102 & 21 \\
2000 & - & - & - & - & - & - & - & - & 22 \\
2001 & - & - & - & - & - & - & - & - & 27 \\
2002 & 76.9 & 20.5 & 2.6 & 0.0 & 0.0 & 39 & 0 & 22 & 12 \\
2003 & - & - & - & - & - & - & - & - & 13 \\
2004 & 85.7 & 14.3 & 0.0 & 0.0 & 0.0 & 28 & 15 & 33 & 16 \\
\hline
\end{tabular}

\section{Kelt data}

The annual number of sea trout kelts recorded in the Tawnyard trap since 1985 has varied considerably (Fig. 4). Kelt numbers were significantly lower in Period B $(z=-2.81, p=0.005)$ compared to Period A. As seen with sea age data (Table 4 ), a reduction in older sea age fish is also evident from kelt length frequency data (Fig. S1 in the Supplement at www.intres.com/articles/suppl/q008p675_supp.pdf). Analysis of kelt length frequency revealed a significant negative effect of period on length, with kelts being significantly smaller in Periods B $(t=-5.21, \mathrm{p}<0.001), \mathrm{C}$ $(t=-3.067, \mathrm{p}=0.008)$ and $\mathrm{D}(t=-3.22, \mathrm{p}=0.005)$ than

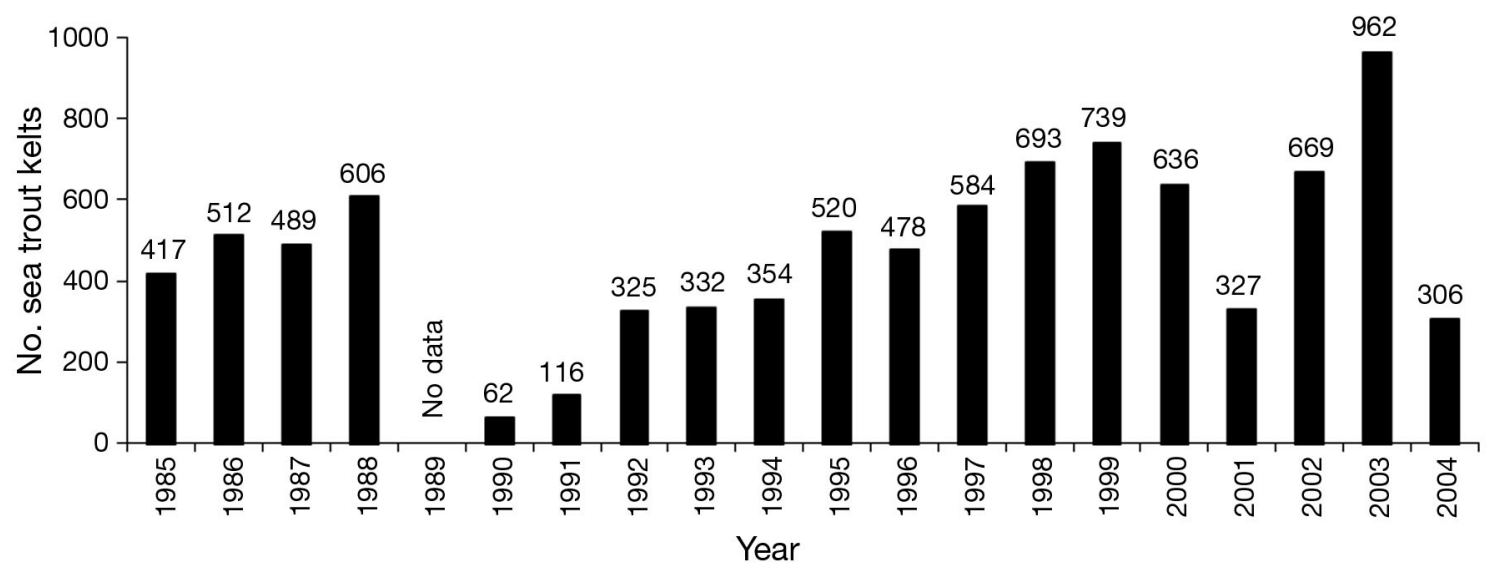

Fig. 4. Annual numbers of sea trout Salmo trutta kelts migrating downstream and captured in the Tawnyard trap between 1985 and 2004 


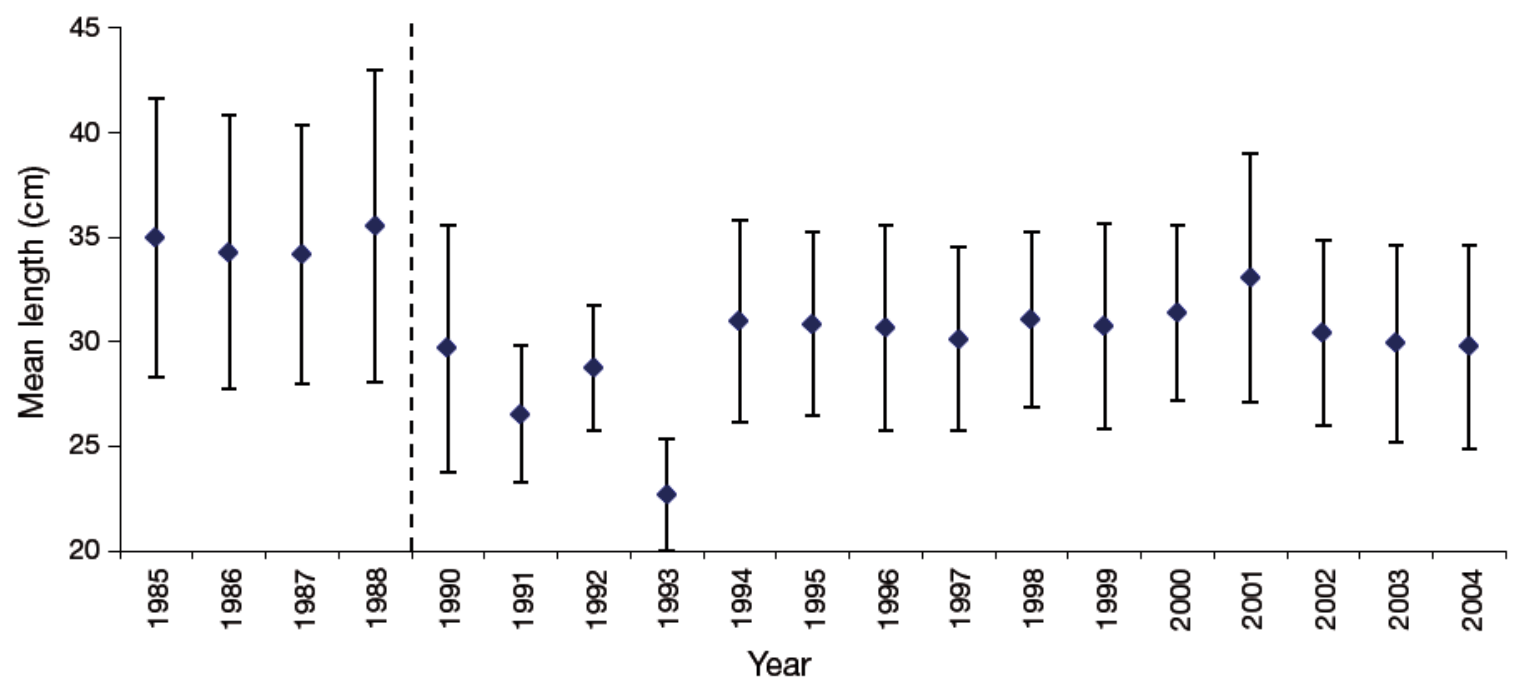

Fig. 5. Mean ( \pm SD) length of sea trout Salmo trutta kelts recorded from the Black River trap, 1985-2004. Kelt data over the period 1985-1988 (to the left of the dashed vertical line) were collected prior to salmon farming

in Period A. Over the 1985-1988 period, the sea trout kelt population structure comprised a finnock peak (length range 27 to $\sim 32 \mathrm{~cm}$ ), a peak of 1 and 2 sea winter fish (35 to $45 \mathrm{~cm}$ ) and some older previous spawners (Fig. S1).

The change in population structure is also evident from mean sea trout kelt length data (Fig. 5). Over the 1985-1988 period, mean kelt length was $>34 \mathrm{~cm}$, ranging from 34.2 to $35.6 \mathrm{~cm}$. After the sea trout stock collapse, the mean length decreased to $<30 \mathrm{~cm}$ from 1990 to 1993 , and remained in the $29-31 \mathrm{~cm}$ range thereafter, with the exception of 2001 (Fig. 5). Thus the kelt population showed both a reduction in mean size and mean sea age after 1990. Prior to 1990, sea trout kelts $>35 \mathrm{~cm}$ in length comprised more than $35 \%$ of the population (Table 4 ). In 1990, only 13 sea trout $(21 \%)$ were recorded $>35 \mathrm{~cm}$ in length (Table 4$)$, and little recovery in size was evident until 1994. Over the 1994-2001 period, and particularly over the 1998-2001 period, the percentage of sea trout kelts $>35 \mathrm{~cm}$ captured in the trap increased, peaking at $27 \%$ in 2001 (Table 4).

\section{Sea trout fecundity}

The potential sea trout egg deposition in the Tawnyard subcatchment is shown over the 1985-2004 period (Fig. 6). A significant negative effect of period was evident in fecundity, with significantly fewer eggs depo- sited annually in Period B $(z=-6.04, \mathrm{p}<0.001)$ than in Period A (Table 5).

\section{Summary of statistical results}

The responses of 15 variables were modelled to evaluate long-term changes in the life history composition and abundance of the Erriff sea trout population. A summary of the model outputs for these responses is presented in Table 5. Models including 'Period' as an explanatory variable captured important changes in various life history characteristics of Erriff sea trout. Period B (covering the $5 \mathrm{yr}$ after salmon farming commenced: 1990-1994) was associated with significant decreases relative to Period A (1985-1988) in the number and length of sea trout

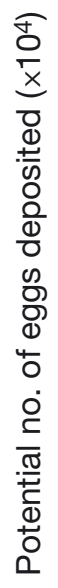

Fig. 6. Estimated potential sea trout Salmo trutta egg deposition, Tawnyard catchment, 1985-2004 


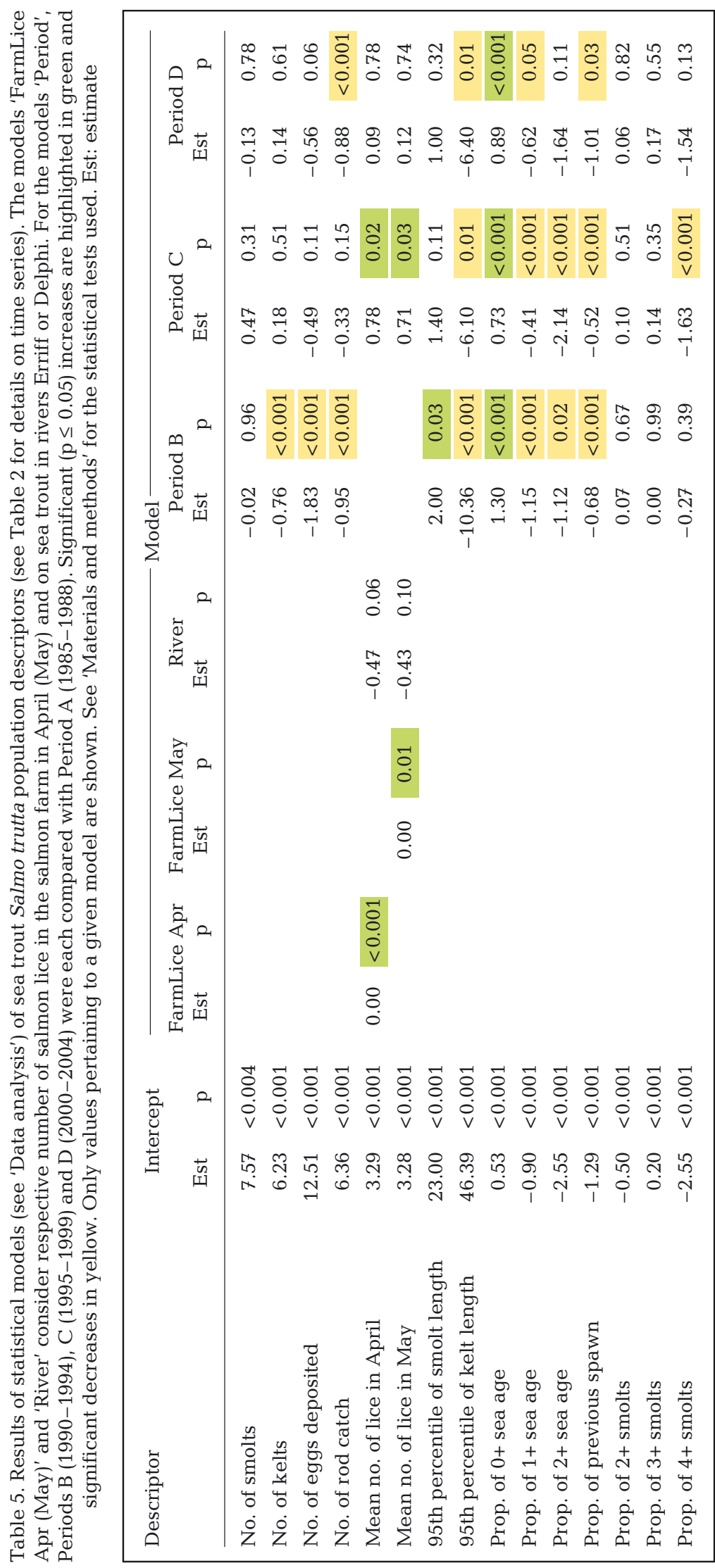

kelts observed, in the estimated number of eggs deposited in the Tawnyard subcatchment and in the sea trout rod catch and the proportion of older $(1+$ and $2+$ sea age) fish and previous spawners captured at Tawnyard. During the same period, the length of smolts and the proportion of younger $(0+$ sea age) fish was significantly greater than that observed previously.

Models assessing the relationship between the numbers of sea lice being produced on the salmon farm and the numbers of lice counted on wild sea trout occurring in the Delphi and Erriff Rivers showed a significant positive relationship between number of lice in the local salmon farm and number of lice on sea trout in both tested months (Table 5). We also found that the number of lice on wild sea trout in these rivers increased between Periods B and C (no data were available for Period A).

\section{DISCUSSION}

Fifteen sea trout population descriptors (response variables) and numbers of lice present in the geographically proximate salmon farm were used to evaluate life history and abundance variation in the Tawnyard sea trout population over a 20 yr period. In the period 1990-1994, immediately after the commencement of salmon farming in Killary Harbour, there were significant decreases in the numbers of sea trout caught, the estimated number of eggs deposited, the number and length of sea trout kelts, the proportion of older maiden spawners and the numbers of previous spawners. We also found a response in the age at which trout smolts went to sea, with younger and larger smolts migrating from the Tawnyard/Glendavock system.

The Erriff data indicate that a stable sea trout population structure typical of western Ireland was present prior to 1989; the population was dominated by a peak of finnock $(0+$ sea age trout of length up to $\sim 32 \mathrm{~cm}$ ), a second peak of 1 sea winter maidens (length up to 
$\sim 40 \mathrm{~cm}$ ) and some older and larger sea age classes and previous return spawners of $>40 \mathrm{~cm}$. Poole et al. (1996) recorded a similar population structure in the Burrishoole prior to 1989, as did Went (1962) for 4 neighbouring fisheries (Ballinahinch, Cashla, Gowla and Bundorragha), with the population dominated by finnock (range 52-83\%), 1 sea winter fish (12-28\%) and smaller numbers of maiden sea age groups and previous spawners. Subsequent to the 1989 sea trout rod catch collapse in western Ireland (Sea Trout Task Force 1994), this typical population structure changed markedly in the Tawnyard population; there was a reduction in the number and proportions of sea age classes, and stocks were characterized by very low returns of finnock and fewer veteran sea trout in the older age classes indicating a collapse in population structure, a feature also recorded in the neighbouring Burrishoole fishery (Poole et al. 1996, 2006). Mortality of older sea age classes was a feature of the stock collapse in both fisheries. Gargan et al. (2006a) assessed sea trout rod CPUE data and found that the sea trout catch collapse recorded in western Irish fisheries over the 1989/1990 period resulted from a marked reduction in CPUE and was not related to reduced angling effort. Some recovery took place both numerically and in population structure over the period 1994-2000 in the Tawnyard subcatchment, with a finnock peak becoming more evident and an increase in the proportion of kelts recorded over $35 \mathrm{~cm}$. However, over the 2001-2004 period, this improvement in population structure was not maintained, and the Tawnyard sea trout kelt population structure evident before 1989 had not re-established itself by the early 2000 s, a feature also observed in the Burrishoole stock (Poole et al. 2006).

Several other studies have documented long-term changes in sea trout population structure. Butler \& Walker (2006) recorded a collapse in sea trout rod catch in the River Ewe/Loch Maree system in Wester Ross, Scotland, in 1988, with an apparently unprecedented reduction in marine growth and survival reflected in marked shifts in the population structure before and after the collapse. Between 1980 and 1997-2001, maximum sea age fell from 11 to $5 \mathrm{yr}$ and marine growth rates declined. This was reflected in the River Ewe rod catch, with significant changes in the body mass distribution of fish between 19711980 and 1992-2001, with the mean falling from 0.54 to $0.34 \mathrm{~kg}$ over the time period. Taken together, the changes in the River Ewe stock structure could be related to declines in marine growth and survival, which were deduced to have been at least partly attributable to salmon lice epizootics emanating from salmon farms in the adjacent coastal waters of the marine embayment of Loch Ewe (Butler \& Walker 2006).

Harris (2006) commented that the structure and composition of a sea trout population will determine its ability to withstand and recover rapidly from any adverse factors in both the freshwater and marine environments. Harris (2006) described a robust sea trout stock as having a range of smolt classes, sea age groups and a high incidence of repeat spawning, which buffers the stock from collapse. There is an increasing understanding of the role life history diversity has on the productivity of salmonid populations and how concepts associated with 'bio-complexity' (Hilborn et al. 2003) and the 'portfolio effect' (Schindler et al. 2010) contribute to our understanding of population resilience.

This philosophy is supported by the fish population state indicators suggested by Froese (2004), which are similar to the response variable descriptors identified in the current study. The sea trout population structure evident over the 1985-1988 period in the present study (with 3 smolt age classes and a range of adult return sea age groups and previous spawners) would fit the description of a robust stock sensu Harris (2006). However, this diversity in life history did not prevent the stock failing dramatically after 1989. No reduction in smolt output was observed in the present study over the 4 time periods examined despite a reduction in the estimated number of eggs deposited by sea trout after 1989, suggesting that the impact on the population was not operating in fresh water. Gargan et al. (2006b) recorded a substantial output of sea trout smolts after an observed reduction in adult sea trout runs in 2 other western Irish fisheries after the 1989/1990 stock collapse and suggested that the freshwater trout population was a major contributor to sea trout smolt output in these years.

Whelan et al. (1993) investigated environmental factors influencing the migration and survival of sea trout stocks in the Burrishoole system during the 1989 stock collapse. They concluded that while environmental factors might play a pivotal role in regulating the number of migrating smolts, they did not provide an explanation for poor marine survival and that the cause of the population crash lay in the marine environment. This was corroborated by Poole et al. (1996), who reported an unprecedented failure of smolts in the sea emanating from the Burrishoole system with high mortality of all age classes of adult sea trout, therefore indicating a primarily marine-based problem. Variations in marine survival of salmon 
have been associated with climate-related changes in the extent of thermal habitat (e.g. Jonsson \& Jonsson 2004, Friedland et al. 2014) and availability of pelagic prey (e.g. Friedland et al. 2009, Beaugrand \& Reid 2012). Similarly, large-scale changes in life history traits, particularly sea age and run time, have been reported in a number of long-term studies (Summers 1995, Boylan 2004, Bacon et al. 2009). These are considered to be responses to broaderscale ecosystem dynamics such as the Atlantic Multidecadal Oscillation (Edwards et al. 2013, Klöwer et al. 2014, Trenkel et al. 2014). It is possible that a changing ocean could be responsible for shifts in the population dynamics of Erriff sea trout observed here. However, there is little information on the factors affecting natural variation in marine survival of sea trout (Thorstad et al. 2016). In coastal habitats influenced strongly by fresh waters, time series of temperature and rainfall for the Erriff catchment (Shephard et al. 2016) do not show long-term trends that would be expected to drive strong changes among sea trout passing their marine phase in these waters. In contrast, the strong period effect in sea trout life history traits observed in the current study suggests a sudden and dramatic shift (around the late 1980s) that appears more consistent with a discrete and point-source pressure event than with directional environmental change.

The change in sea trout population dynamics observed in the present study is unlikely to have resulted from an increase in freshwater or marine exploitation or to any fisheries-induced change associated with the prosecution of a size-selective fishery. In fresh water, angling methods were restricted to fly only, and catch-and-release was introduced from 1990 onwards. No increase in commercial salmon fisheries took place over the study period, and while some sea trout were captured as a bycatch in commercial salmon fisheries, there was a ban from 1990 on the sale of sea trout and consequently commercial fishermen were obliged to return all sea trout to the water under the conditions of the commercial bylaw in operation (Gargan et al. 2006a). Other regulations introduced after 1990 included extended sanctuary areas outside Killary Harbour where drift netting for salmon and sea trout was prohibited (Sea Trout Task Force 1994).

The change in sea trout population dynamics observed in the Tawnyard stock is also mirrored in the rod catch data for both the Erriff catchment and the Connemara District. Both rod catch data series show a relatively stable catch up until 1988. The sea trout rod catch collapse evident in the Connemara rod catch data over the 1989/1990 period previously described (Poole et al. 1996, Gargan 2000) is also evident in the Erriff rod catch data. Data from the present study demonstrate that this rod catch collapse was associated with a significant reduction in the number of kelts and proportion of older sea age classes and a breakdown in population structure.

The 1989 spawning stock collapse in western Ireland significantly reduced both the total number of sea trout eggs deposited and subsequent levels of recruitment (Poole et al. 2006). O'Farrell et al. (1989) showed that sea trout $\geq 35 \mathrm{~cm}$ (1+ and $2+$ sea age fish) make the greatest contribution ( $75.9 \%$ of all ova) to egg deposition in the Erriff catchment. Results from the present study indicate that fewer eggs were deposited after 1989 than in the pre-collapse period. Hence, reduced marine survivorship of larger, older spawners which contribute disproportionately to overall egg deposition can exert considerable and rapid impacts on adult fish abundance at the population level.

A statistically significant relationship between lice infestation on sea trout and distance to the nearest salmon farm in Ireland was observed over a $10 \mathrm{yr}$ period, with highest infestations and variation in infestation seen close to fish farms (Gargan et al. 2003). In the current study, we also show a significant relationship between the production of lice in a local farm and the numbers of lice occurring on wild sea trout collected in the Erriff and Delphi Rivers. A similar trend has been recorded in Scottish (Mackenzie et al. 1998, Butler \& Watt 2003, Middlemas et al. 2013) and Norwegian studies (Birkeland \& Jakobsen 1997, Bjørn et al. 2001, 2011, Serra-Llinares et al. 2014). Gargan et al. (2003) examined the relationship between sea trout marine survival and the mean abundance of lice infestation in the sea trout population in 4 bays in western Ireland (including Killary Harbour) over the 1992-2001 period and showed a significant negative relationship between sea trout survival and the level of lice infestation. Tully et al. (1999) demonstrated that the presence of salmon farms significantly increased the level of sea lice infestation on sea trout post smolts in Ireland. Similar findings have been reported from Norway (Grimnes et al. 2000) and Scotland (Mackenzie et al. 1998, Butler 2002). In a recent study, Taranger et al. (2015) undertook a risk assessment of the effects of salmon lice on wild salmonid populations along the intensively farmed Norwegian coastline and found that sea trout from the majority of sampled sites had salmon lice infections, mainly resulting from salmon farming, which indicated moderate or high mortality 
risk of sea trout. In an extensive review of the impacts of the salmon louse on sea trout, Thorstad et al. (2015) concluded that salmon farming increases the abundance of salmon lice in the marine habitat, and there is extensive published evidence that salmon lice in intensively farmed areas have negatively impacted wild sea trout populations by increasing marine mortality, changes in migratory behaviour, reduction of marine growth and reduced population sizes. Results of this long-term monitoring programme on the River Erriff demonstrate that significant change in sea trout population life history composition and abundance can occur over a relatively short time period and suggest that the introduction of salmon farming in the local estuary most likely contributed to the observed changes. Recent data indicate that the sea trout population structure and sea age composition observed before 1990 has not yet become re-established in the Tawnyard population.

Acknowledgements. We thank Dr. Martin O'Farrell and Roy Peirce for undertaking detailed assessments of Tawnyard sea trout stocks over the early study period. Dr. David Solomon is acknowledged for previous advice on calculation of sea trout fecundity estimates. The staff of the former Western Regional Fisheries Board, particularly James Stafford and Martin Wallace, are acknowledged for undertaking annual monitoring of the Tawnyard trap.

\section{LITERATURE CITED}

Allan JRH, Ritter JA (1977) Salmonid terminology. J Cons Int Explor Mer 37:293-299

Bacon PJ, Palmer SCF, MacLean JC, Smith GW, Whyte BDM, Gurney WSC, Youngson AF (2009) Empirical analyses of the length, weight, and condition of adult Atlantic salmon on return to the Scottish coast between 1963 and 2006. ICES J Mar Sci 66:844-859

Beaugrand G, Reid PC (2012) Relationships between North Atlantic salmon, plankton, and hydroclimatic change in the Northeast Atlantic. ICES J Mar Sci 69:1549-1562

Birkeland K, Jakobsen PJ (1997) Salmon lice, Lepeophtheirus salmonis, infestation as a causal agent of premature return to rivers and estuaries by sea trout, Salmo trutta, juveniles. Environ Biol Fishes 49:129-137

Bjørn PA, Finstad B, Kristoffersen R (2001) Salmon lice infection of wild sea trout and Arctic char in marine and freshwaters: the effects of salmon farms. Aquacult Res 32:947-962

Bjørn PA, Sivertsgård R, Finstad B, Nilsen R, Serra-Llinares RM, Kristoffersen R (2011) Area protection may reduce salmon louse infection risk to wild salmonids. Aquacult Environ Interact 1:233-244

Boylan P (2004) Dynamics of the Atlantic salmon (Salmo salar L.) population of the River Foyle, Ireland. PhD thesis, Glasgow University

Butler JRA (2002) Wild salmonids and sea louse infestations on the west coast of Scotland: sources of infection and implications for the management of marine salmon farms. Pest Manag Sci 58:595-608

Butler JRA, Walker AF (2006) Characteristics of the sea trout Salmo trutta (L.) stock collapse in the River Ewe (Wester Ross, Scotland), in 1988-2001. In: Harris G, Milner N (eds) Sea trout: biology, conservation and management. Blackwell Publishing, Oxford, p 45-59

Butler JRA, Watt J (2003) Assessing and managing the impacts of marine salmon farms on wild Atlantic salmon in Western Scotland: identifying priority rivers for conservation. In: Mills D (ed) Salmon at the edge. Proceedings of the 6th International Atlantic Salmon Symposium, Edinburgh, UK, July 2002. Blackwell Publishing, Oxford, p 93-118

Davidson IC, Cove RJ, Hazlewood MS (2006) Annual variation in age composition, growth and abundance of sea trout returning to the river Dee at Chester, 1991-2003. In: Harris G, Milner N (eds) Sea trout: biology, conservation and management. Blackwell Publishing, Oxford, p 76-87

Edwards M, Beaugrand G, Helaouet P, Alheit J, Coombs S (2013) Marine ecosystem response to the Atlantic Multidecadal Oscillation. PLOS ONE 8:e57212

Elliott JM (1985) Population dynamics of migratory trout, Salmo trutta, in a Lake District stream, 1966-83, and their implications for fisheries management. J Fish Biol 27(Suppl A):35-43

Fisheries Research Services (2002) Shieldaig Project Review, June 2001-June 2002. Internal Report. Fisheries Research Services, Pitlochry

Friedland KD, MacLean JC, Hansen LP, Peyronnet AJ and others (2009) The recruitment of Atlantic salmon in Europe. ICES J Mar Sci 66:289-304

Friedland KD, Shank BV, Todd CD, McGinnity P, Nye JA (2014) Differential response of continental stock complexes of Atlantic salmon (Salmo salar) to the Atlantic Multi decadal Oscillation. J Mar Syst 133:77-87

Froese R (2004) Keep it simple: three indicators to deal with overfishing. Fish Fish 5:86-91

Gargan PG (2000) The impact of the salmon louse (Lepeophtheirus salmonis) on wild salmonid stocks in Europe and recommendations for effective management of sea lice on salmon farms. In: Gallaugher P, Orr C (eds) Aquaculture and the protection of wild salmon. Workshop Proceedings, July 2000. Simon Fraser University, Vancouver, BC, p 37-46

Gargan PG, Tully O, Poole WR (2003) The relationship between sea lice infestation, sea lice production and sea trout survival in Ireland, 1992-2001. In: Mills D (ed) Salmon at the edge. Proceedings of the 6th International Atlantic Salmon Symposium, Edinburgh, UK, July 2002. Blackwell Publisching, Oxford, p 119-135

Gargan PG, Poole WR, Forde GP (2006a) A review of the status of Irish sea trout stocks. In: Harris G, Milner N (eds) Sea trout biology, conservation and management. Blackwell Publishing, Oxford, p 25-44

Gargan PG, Roche WK, Forde GP, Ferguson A (2006b) Characteristics of the sea trout (Salmo trutta L.) stocks from the Owengowla and Invermore fisheries, Connemara, Western Ireland, and recent trends in marine survival. In: Harris G, Milner N (eds) Sea trout: biology, conservation and management. Blackwell Publishing, Oxford, p 60-75

Grimnes A, Finstad B, Bjorn PA (2000) Registrations of salmon lice on Atlantic salmon, sea trout and charr in 1999. NINA Oppdragsmeld 634:1-34 (In Norwegian with 
English Abstract)

Harris GS (2006) Sea trout stock descriptions in England and Wales. In: Harris G, Milner N (eds) Sea trout: biology, conservation and management. Blackwell Publishing, Oxford, p 88-106

Hilborn R, Quinn TP, Schindler DE, Rogers DE (2003) Biocomplexity and fisheries sustainability. Proc Natl Acad Sci USA 100:6564-6568

Jackson D, Minchin D (1993) Lice infestations of farmed salmon in Ireland. In: Boxshall GA, Defaye D (eds) Pathogens of wild and farmed fish. Ellis Horwood Ltd, London, p 188-201

Jonsson B (1985) Life history patterns of freshwater resident and sea-run migrant brown trout in Norway. Trans Am Fish Soc 114:182-194

Jonsson B, Jonsson N (2004) Factors affecting marine production of Atlantic salmon (Salmo salar). Can J Fish Aquat Sci 61:2369-2383

Klöwer M, Latif M, Dinga H, Greatbatcha RJ, Parka W (2014) Atlantic meridional overturning circulation and the prediction of North Atlantic sea surface temperature. Earth Planet Sci Lett 406:1-6

Le Cren ED (1985) The biology of the sea trout. Summary of a symposium held at Plas Menai, 24-26 October 1984. Sponsored by the Welsh Water Authority and the Atlantic Salmon Trust, Pitlochry

Mackenzie K, Longshaw M, Begg GS, McVicar AH (1998) Sea lice (Copepoda: Caligidae) on wild sea trout (Salmo trutta L.) in Scotland. ICES J Mar Sci 55:151-162

Middlemas SJ, Fryer RJ, Tulett D, Armstrong JD (2013) Relationship between sea lice levels on sea trout and fish farm activity in western Scotland. Fish Manag Ecol 20:68-74

Mills CPR, Piggins DJ, Cross TF (1990) Burrishoole sea trout: a twenty year study. 20th Annual Study Course Proceedings. Institute of Fisheries Management, London, p 61-78

Nall GH (1930) The life of the sea trout: especially in Scottish waters. Seeley, Service \& Co., London

O'Farrell MM, Whelan KF, Whelan BJ (1989) A preliminary appraisal of the fecundity of migratory trout (Salmo trutta) in the Erriff catchment, Western Ireland. Pol Arch Hydrobiol 36:273-281

Poole WR, Whelan KF, Dillane MG, Cooke DJ, Matthews M (1996) The performance of sea trout, Salmo trutta L., stocks from the Burrishoole system western Ireland, 1970-1994. Fish Manag Ecol 3:73-92

Poole WR, Byrne CJ, Dillane MG, Whelan KF, Gargan PG (2002) The Irish Sea Trout Enhancement Programme: a review of the broodstock and ova production programmes. Fish Manag Ecol 9:1-14

Poole WR, Dillane M, DeEyto E, Rogan G, McGinnity P, Whelan K (2006) Characteristics of the Burrishoole sea trout population: census, marine survival, enhancement and stock-recruitment relationship, 1971-2003. In: Harris G, Milner N (eds) Sea trout: biology, conservation and management. Blackwell Publishing, Oxford, p 107-114
R Development Core Team (2010) R: a language and environment for statistical computing. R Foundation for Statistical Computing, Vienna

K Schindler DE, Hilborn R, Chasco B, Boatright CP, Quinn TP, Rogers LA, Webster MS (2010) Population diversity and the portfolio effect in an exploited species. Nature 465:609-612

Sea Trout Task Force (1994) Report of the Sea Trout Task Force. Department of the Marine, Dublin

* Serra-Llinares RM, Bjørn PA, Finstad B, Nilsen R, Harbitz A, Berg M, Asplin L (2014) Salmon lice infection on wild salmonids in marine protected areas: an evaluation of the Norwegian 'National Salmon Fjords'. Aquacult Environ Interact 5:1-16

Shephard S, MacIntyre C, Gargan P (2016) Aquaculture and environmental drivers of salmon lice infestation and body condition in sea trout. Aquacult Environ Interact 8:597-610

Solomon DJ (1995) Sea trout stocks in England and Wales. R\&D Report 25. National Rivers Authority, Bristol

* Summers DW (1995) Long-term changes in sea-age of maturity and seasonal time of return of salmon (Salmo salar L.) to Scottish rivers. Fish Manag Ecol 2:147-156

Taranger GL, Karlsen Ø, Bannister RJ, Glover KA and others (2015) Risk assessment of the environmental impact of Norwegian Atlantic salmon farming. ICES J Mar Sci 72:997-1021

Thorstad EB, Todd CD, Uglem I, Bjørn PA and others (2015) Effects of salmon lice Lepeophtheirus salmonis on wild sea trout Salmo trutta-a literature review. Aquacult Environ Interact 7:91-113

* Thorstad EB, Todd CD, Uglem I, Bjørn PA and others (2016) Marine life of the sea trout. Mar Biol 163:47

Trenkel VM, Huse G, MacKenzie BR, Alvarez P and others (2014) Comparative ecology of widely distributed pelagic fish species in the North Atlantic: implications for modelling climate and fisheries impacts. Prog Oceanogr 129:219-243

Tully O, Poole WR, Whelan KF (1993) Infestation parameters for Lepeophtheirus salmonis (Krøyer) (Copepoda: Caligidae) parasitic on sea trout, Salmo trutta L., off the west coast of Ireland during 1990 and 1991. Aquacult Fish Manag 24:545-557

Tully O, Gargan P, Poole WR, Whelan KF (1999) Spatial and temporal variation in the infestation of sea trout (Salmo trutta L.) by the caligid copepod Lepeophtheirus salmonis (Krøyer) in relation to sources of infection in Ireland. Parasitology 119:41-51

Went AEJ (1962) Irish sea trout, a review of investigations to date. Sci Proc R Dublin Soc Ser A 1:265-296

Whelan KF, Galvin PT, Poole WR, Cooke DJ (1993) Environmental factors influencing the migration and survival of sea trout (Salmo trutta L.) smolts. ICES 1993/M48. ICES, Copenhagen

* Wolf P (1951) A trap for the capture of fish and other organisms moving downstream. Trans Am Fish Soc 80:41-45 
APPENDIX

Table A1. Duration and start and end dates (given as dd/yy) of trapping at Tawnyard Trap, 1985 to 2004 . Flood events and incidences of overtopping are shown

\begin{tabular}{|c|c|c|c|c|c|}
\hline Year & $\begin{array}{l}\text { No. trapping } \\
\text { days }\end{array}$ & $\begin{array}{l}\text { Trapping } \\
\text { start date }\end{array}$ & $\begin{array}{l}\text { Trapping } \\
\text { end date }\end{array}$ & Flood events & Comments \\
\hline 1985 & 46 & $11 / 03$ & $26 / 04$ & None recorded & \\
\hline 1986 & 141 & $16 / 01$ & 06/06 & $\begin{array}{c}3 \mathrm{~d}(4-6 / 03) \\
10 \mathrm{~d}(19-29 / 03) \\
3 \mathrm{~d}(16-18 / 04)\end{array}$ & $\begin{array}{l}\text { Flood } \\
\text { Trap closed \& lifted } \\
\text { Trap overtopped }\end{array}$ \\
\hline 1987 & 171 & $16 / 12$ & 05/06 & None recorded & \\
\hline 1988 & 188 & $28 / 10$ & $01 / 06$ & None recorded & \\
\hline 1989 & - & - & - & - & Trap not in operation \\
\hline 1990 & 120 & $11 / 02$ & $11 / 06$ & None recorded & \\
\hline 1991 & 88 & $22 / 03$ & $18 / 06$ & $2 \mathrm{~d}(10-11 / 04)$ & Flood \\
\hline 1992 & 78 & $28 / 03$ & $14 / 06$ & $2 \mathrm{~d}(23-24 / 04)$ & Trap topped \\
\hline 1993 & 68 & $23 / 03$ & $31 / 05$ & $1 \mathrm{~d}(18 / 05)$ & Trap topped and left open \\
\hline 1994 & 86 & $17 / 03$ & $10 / 06$ & None recorded & \\
\hline 1995 & 86 & $14 / 03$ & $07 / 06$ & None recorded & \\
\hline 1996 & 98 & 07/03 & $12 / 06$ & None recorded & \\
\hline 1997 & 97 & $05 / 03$ & 09/06 & $\begin{array}{c}1 \mathrm{~d}(7 / 03) \\
1 \mathrm{~d}(28 / 04)\end{array}$ & $\begin{array}{l}\text { Flood } \\
\text { Flood }\end{array}$ \\
\hline 1998 & 108 & $25 / 02$ & $12 / 06$ & $\begin{array}{c}2 \mathrm{~d}(6-7 / 05) \\
1 \mathrm{~d}(9 / 06)\end{array}$ & $\begin{array}{l}\text { Trap topped } \\
\text { Flood }\end{array}$ \\
\hline 1999 & 106 & $22 / 02$ & 07/06 & $\begin{array}{l}2 \mathrm{~d}(14-15 / 03) \\
1 \mathrm{~d}(28 / 03) \\
2 \mathrm{~d}(5-6 / 04) \\
2 \mathrm{~d}(11-12 / 05) \\
1 \mathrm{~d}(25 / 05)\end{array}$ & $\begin{array}{l}\text { Flood } \\
\text { Flood } \\
\text { Small flood } \\
\text { Large flood, trap almost topped } \\
\text { Small flood }\end{array}$ \\
\hline 2000 & 81 & $25 / 03$ & $13 / 06$ & $1 \mathrm{~d}(20 / 04)$ & Medium flood \\
\hline 2001 & 50 & $28 / 03$ & $17 / 05$ & None recorded & \\
\hline 2002 & 82 & $15 / 03$ & $04 / 06$ & None recorded & \\
\hline 2003 & 50 & $25 / 03$ & $13 / 05$ & $1 \mathrm{~d}(26 / 03)$ & Flood \\
\hline 2004 & 102 & 03/03 & $12 / 06$ & $1 \mathrm{~d}(17 / 03)$ & Flood \\
\hline
\end{tabular}

Editorial responsibility: Bengt Finstad, Trondheim, Norway
Submitted: January 21, 2016; Accepted: November 18, 2016 Proofs received from author(s): December 20, 2016 